\title{
All sites but skin cancer incidences analyzed worldwide by sex, age, and skin type over time (1955-2007), advancing age, and UVB dose reveals important carcinogenic drivers
}

\author{
Dianne E. Godar*1, Rossen Gurov², Stephen J. Merrill ${ }^{3}$ \\ ${ }^{1}$ Division of Human Disease Research Worldwide, Body of Knowledge, Inc., Racine, WI, United States \\ ${ }^{2}$ Department of Biochemistry, College Park, University of Maryland, MD, United States \\ ${ }^{3}$ Department of Mathematics, Statistics, and Computer Science, Marquette University, Milwaukee, WI, United States
}

Received: April 19, 2017

DOI: $10.5430 /$ jer.v3n2p65
Accepted: June 20, 2017

Online Published: August 31, 2017

\begin{abstract}
Because we observed increasing incidences over time, advancing age, higher estrogen levels, decreasing UVB (290-315 nm) doses, or lower vitamin $\mathrm{D}_{3}$, and Human Papillomavirus hiding in immune-privileged sites of hair follicles play roles in melanoma, we wondered if the majority of cancers might have similar carcinogenic drivers. To investigate this possibility, we performed worldwide analysis of all sites but skin cancer over time (1955-2007), advancing age, and UVB doses for males and females with all skin types and ages (0-85+) and in five age groups using IARC data. To investigate Human Papillomavirus's role, we analyzed the incidences of breast, prostate, and colon cancers in a developed country with European ancestry (New Zealand) having high amounts of androgenic hair and a developing country with Asian ancestry (India) having low amounts of androgenic hair. To potentially add epidemiology to the already established role of estrogen in cancer, we analyzed males and females in various countries around the world using the incidence of breast cancer ( $>70 \mathrm{yr}$.) as an established indicator of estrogen levels. The analysis reveals cancer incidences are steadily increasing over time in developed but not developing countries regardless of skin type. Only US white, but not black, breast, prostate, and colon cancer incidences in the oldest age group significantly decreased with increasing UVB dose suggesting a role for vitamin $\mathrm{D}_{3}$. The data suggests the carcinogenic drivers in many cancers are estrogen, increasing age (or reactive oxygen species), decreasing vitamin $\mathrm{D}_{3}$ levels, and persistence of Human Papillomavirus infection in immune-privileged sites.
\end{abstract}

Key Words: Aging, Estrogen, Human Papilloma Virus, Reactive Oxygen Species, Ultraviolet, Vitamin $\mathrm{D}_{3}$

\section{INTRODUCTION}

Cancer is the second leading cause of human death worldwide. In 2015, there were 17.5 million new cancer cases and 8.7 million cancer deaths worldwide. ${ }^{[1]}$ For men, prostate cancer (1.6 million cases) was the most common; for women, breast cancer (2.4 million cases) was the most common; for both sexes, colon and rectum cancers (1.78 million) were the third most prevalent cancers worldwide. Alarmingly, the incidence of all cancers rose 33\% in only one decade (20052015); prostate cancer rose $66.1 \%$, breast cancer rose $43 \%$,

\footnotetext{
*Correspondence: Dianne E. Godar; Email: diannegodar@yahoo.com; Address: Division of Human Disease Research Worldwide, Body of Knowledge, Inc., Racine, WI, United States.
} 
and colon cancer rose $36.5 \%$.

DNA mutations and genomic instability primarily cause cancer. These alterations in the DNA can occur through physical, chemical, or biological agents. For example, we know cumulative doses of UV radiation (UVR; 280-400 nm) increase the risk for getting non-melanoma skin cancer; ${ }^{[2]}$ estrogen $^{[3,4]}$ and BRAC 1 and 2 mutations $^{[5]}$ increase the risk for getting breast cancer; Human Papillomavirus (HPV) infections cause genomic instability that increases the risk for getting cervical ${ }^{[6]}$ and oropharyngeal cancers. ${ }^{[7]}$ UVB radiation (280-315 nm) directly causes DNA damage as cyclobutane pyrimidine dimers, while UVA radiation (316-400 $\mathrm{nm}$ ) indirectly causes oxidative DNA damage by creating reactive oxygen species (ROS) that makes 8-oxo-dGuanine, ${ }^{[8]}$ which is later incorporated into the DNA leading to subsequent mutations. ${ }^{[9]}$ UVA radiation also causes oxidation of cytosines leading to deamination and subsequent $\mathrm{C} \rightarrow \mathrm{T}$ transition mutations. ${ }^{[10]}$

Besides DNA mutations and genomic instability, epigenetic events can affect cancer formation via the production of soluble factors like inflammatory cytokines, vitamin $\mathrm{D}_{3}$, estrogen, ROS, or methylation of DNA bases. For example, the inflammatory cytokines produced by UVB-irradiated skin and oral tissue cells ${ }^{[11]}$ circulate systemically increasing the risk for getting cervical, pharyngeal, ${ }^{[12]}$ and many other cancers. ${ }^{[13]}$ In contrast, UVB produces vitamin $\mathrm{D}_{3}$ in the skin ${ }^{[14]}$ that also circulates systemically and may counter the effects of the inflammatory cytokines and possibly even decrease the risk for getting some cancers. ${ }^{[15]}$ UVA radiation creates ROS that can further contribute toward carcinogenesis by activating HPV ${ }^{[16]}$ and combined with estrogen cause increased expression of HPV's oncogenic proteins E6 and $\mathrm{E}^{[17]}$ that immortalize cells by inactivating $\mathrm{p} 53$ and $\mathrm{pRB}$, respectively. ${ }^{[18]}$ ROS synergistically increases the risk for getting cancer when combined with estrogen, as shown in a hamster kidney cancer model. ${ }^{[19]}$ Estrogen has also been declared a human carcinogen by the International Agency for Research on Cancer (IARC) ${ }^{[20]}$ because it increases the risk for females getting cervical, breast, ovarian, and endometrial cancers; ${ }^{[21]}$ estrogen also increases the risk for males getting breast ${ }^{[22]}$ and prostate cancers. ${ }^{[23-25]}$ Finally, epigenetic methylation of cytosines from the virally-induced APOBEC system results in deamination of cytosines creating driver mutations in the PIK3CA gene ${ }^{[26-28]}$ found in various cancers, ${ }^{[29]}$ which are associated with HPV signature mutations. ${ }^{[30]}$

We know high risk HPV's (primarily 16 and 18) are definitely involved in cervical, pharyngeal, penile, anal, vaginal, and vulva cancers ${ }^{[31]}$ and recently meta-analysis suggests
HPV is probably involved in other cancers as well such as lung, ${ }^{[32,33]}$ prostate, ${ }^{[34,35]}$ breast, ${ }^{[36]}$ colon, ${ }^{[37]}$ ovarian, ${ }^{[38]}$ bladder, ${ }^{[39]}$ and non-melanoma skin cancer. ${ }^{[40]}$ In addition, HPV has been found in cancers like cutaneous malignant melanoma, ${ }^{[41,42]}$ eye, ${ }^{[43]}$ esophageal, ${ }^{[44]}$ and stomach. ${ }^{[45,46]}$ HPV may be the reason some cancers are recently increasing over time like pancreas, liver, thyroid, and kidney, ${ }^{[47]}$ and is possibly involved in other cancers that have not yet been discovered. Moreover, children, babies, and fetuses can be infected with HPV because it can cross the placenta, ${ }^{[48]}$ which may explain the recent (1975-2012) 0.6\%/year rise in childhood cancers. ${ }^{[49]}$ Persistent HPV infection is responsible for over $90 \%$ of cervical and anal cancers, around $70 \%$ of vulvar, vaginal, and oropharynx cancers, and over $60 \%$ of penile cancers the rates of which vary by race and ethnicity: Hispanics and blacks $>$ whites $>$ Asian and Pacific Islanders. ${ }^{[50]}$

If a cancer is steadily increasing over time beyond what genetic inheritance predicts, like cutaneous malignant melanoma, ${ }^{[51,52]}$ that may indicate HPV infection is involved because its incidence has been documented to be increasing dramatically over recent decades in Europe ${ }^{[53]}$ and in the United States (US). ${ }^{[7]}$ However, depending on the type of cancer, the increasing incidence over time could be due to the spread of other infectious diseases like herpesviruses (EBV and KSHV), polyomaviruses (SV40, MCV, BK, and $\mathrm{JCV}$ ), hepadnaviruses (HBV), flaviviruses (HCV), defective viruses (HDV), retroviruses (HTLV-I, HTLV-II, HIV-1, HIV2, HERV-K, and XMRV), and bacteria, like H. pylori, S. typhi, S. bovis, Bartonella, and C. pneumonia, as well as protozoa, like $P$. falciparum, and parasites like trematodes, like S. haematobium, S. japonicum, S. mansoni, O. viverrini, O. felineus, and C. sinensis. ${ }^{[54]}$ In previous studies, we analyzed cutaneous malignant melanoma over time all over the world $^{[51]}$ and also over personal UVB dose in Europe ${ }^{[52]}$ and found an exponential increase in the incidence from 1955 to 2007 for only people of European ancestry. We speculated a viral infection like HPV might be involved because the rate only began to increase significantly over time, and increased with decreasing personal UVB dose only after 1960, implying increasing time indoors causing low levels of vitamin $D_{3}$ may be promoting infection. ${ }^{[52]}$ Vitamin $D_{3}$ has been gradually decreasing over several decades, as noted by the increasing trend of its inversely related parathyroid hormone. ${ }^{[55]}$ Our recent analysis of melanoma incidences around the world provided evidence that HPV persists in immune privileged androgenic hair follicles where melanocytes, keratinocytes, and stem cells reside. ${ }^{[51]}$ In fact, HPV may be able to hide in many other immune privileged sites throughout the body: (fetus), brain, eye, mucosa, gut, testis, liver, 
skin, lymph node, and tumors. ${ }^{[56]}$

We reasoned that if the majority of cancers are actually caused or promoted by HPV, then we would expect to see "fingerprints" of its involvement such as increasing incidence over time, age, estrogen (comparing male and female incidences over age), and decreasing UVB doses (lower vitamin $\mathrm{D}_{3}$ levels). To test this hypothesis, we used IARC data to perform a worldwide analysis of all sites but skin cancer over time (1955-2007), advancing age, and UVB doses for males and females of all skin types and ages (0-85+) and in five age groups (0-14, 15-29, 30-49, 50-69, and 70-85+). The advantage of using the extensive IARC dataset, is that it is a cancer registry of all cancers reported, and no sampling (or the associated statistics) is required or appropriate. A second advantage of the IARC dataset, is that, although rich and extensive, it has not been extensively used in analyses as presented here. The primary approach utilized here is to examine, through regression, the relationship in variables under study in different regions in the world, which differ in aspects in the variables above - especially skin type and UV dose. In order to discover which cancers might be driving the increase over time, we analyzed the cancers with the highest incidences in males and females (breast, prostate, and colon) in a developed country (New Zealand) with European ancestry and high amounts of androgenic body hair and in a developing country (India) with Asian ancestry and low amounts of androgenic body hair. To uncover the role of estrogen levels in many populations worldwide, we compared males and females over advancing age and used the highest incidence of breast cancer, which occurs over $70 \mathrm{yr}$., as an indicator of estrogen levels. We also analyzed five age groups of male and female breast, prostate, and colon cancers over UVB dose for whites and blacks in the US to see if vitamin $\mathrm{D}_{3}$ affects the risk.

\section{Materials AND MethodS}

2.1 Analysis approach for all sites but skin cancer incidences by sex, age, and countries' skin type over time (1955-2007)

We analyzed the national average, or aggregated the regional population-based cancer registry data to get the national average, of the cancer incidences from IARC. ${ }^{[57]}$ We used the male and female age-standardized 'all sites but skin' (COO96bC44) cancer incidence rates (ASR) per 100,000 world standard population for either all ages $(0-85+)$ or five age groups $(0-14,15-29,30-49,50-69,70-85+)$ at 5-year interval midpoints over time from 1955 to 2007 and the country's, state's, regions', or territories' average UVB dose. We previously described the Fitzpatrick skin type ${ }^{[58]}$ designations for the populations in the different countries, the latitudes and UVB doses used, and the details of the method of analysis. $^{[12,51,52]}$

Quality control involved an assessment of the validity, completeness, and comparability of the incidence data, the details of which IARC provides online. ${ }^{[57]}$ The IARC cancer incidence data includes all tumor stages, thicknesses, histological subtypes, and body site locations. We analyzed 60 countries around the world whenever they began collecting data until 2007 , but note that some countries did not collect data during certain time intervals between 1955 and 2007.

The only country added into this analysis that was not included in our previously published studies ${ }^{[51,52]}$ is Thailand where we analyzed over time, advancing age, and UVB doses for skin type III-IV populations in Bangkok $\left(13.8^{\circ} \mathrm{N}\right)$, Chiang Mai $\left(18.8^{\circ} \mathrm{N}\right)$, Chonburi $\left(13.4^{\circ} \mathrm{N}\right)$, Khon Kaen $\left(16.4^{\circ} \mathrm{N}\right)$, Lampang $\left(16.4^{\circ} \mathrm{N}\right)$, and Songkhla $\left(7.2^{\circ} \mathrm{N}\right)$.

\subsection{Analysis of specific cancers for all ages over time in New Zealand and India: breast, prostate, and colon}

We analyzed specific cancers known to have the highest incidences in males and females worldwide to see which ones were increasing or decreasing over time and causing the 'all sites but skin' cancer incidence changes we observed in the overall cancer analysis shown in Figure 1. Using IARC data, ${ }^{[57]}$ we analyzed the age-standardized cancer incidence rates (ASR) per 100,000 world-standard population at the 5-year interval midpoint in 2005 (2003-2007) for males and females of all ages (0-85+) in New Zealand and India for three specific cancers, breast (C50), prostate (C61), and colon (C18), and display the results in Figure 2.

\subsection{Analysis over the advancing age of the individual}

In Figure 3, we display the age-standardized cancer incidence rates (ASR) per 100,000 world-standard population at the 5-year interval midpoint in 2005 (2003-2007) over the advancing age of males or females based on the average age of each age group. To plot the data over the advancing age of the individual in the five age groups 0-14, 15-29, 30-49, 50-69, 70-85+, we used 7, 22, 40, 60 and 80 yrs. respectively.

\subsection{Analysis of breast cancer incidences of the older (70- 85+) males and females by countries' skin type}

Using IARC data, ${ }^{[57]}$ we also analyzed the age-standardized breast (C50) cancer incidence rates (ASR) per 100,000 worldstandard population at the 5-year interval midpoint in 2005 (2003-2007) by the country's, state's, regions', or territories' skin type for males and females in the oldest age group (70-85+) and display the data in Figure 4. 
2.5 Analysis of specific cancers by age group over UVB dose for whites and blacks in the US: breast, prostate, and colon

To see if UVB dose affects the incidence of some cancers, we analyzed the US regional population-based cancer registry incidences in each state with available data for the white and black, male and female age-standardized breast (C50), prostate (C61), and colon (C18) cancer incidence rates (ASR) per 100,000 world standard population for five age groups $(0-14,15-29,30-49,50-69,70-85+)$ using IARC data. ${ }^{[57]} \mathrm{We}$ used the 5-year interval midpoint for the 2005 data to analyze each cancer over estimated residential UVB dose using the population weighted latitude for each state as previously described. ${ }^{[12,52]}$ This equation is based on actual measurements of people's outdoor UVB doses and that planar dose was changed to an estimated whole body dose using cylinder geometry at all angles.

Briefly the equation is: UVB dose $=-280 \mathrm{X}+22,000$ where $\mathrm{X}$ is the latitude.

\section{RESUlts}

To search for potential patterns and possible similarities and differences between cancer incidences of all the countries populations with different skin types and ancestry, we analyzed the incidences of all sites but skin cancer for males and females in all age groups (0-85+) in almost every country around the world (see Figure 1). We found the incidence of all sites but skin cancer is only significantly increasing in a steady manner over time in certain countries shown in the top four panels, except Italy (see Table 1 for $p$ values), while it is either stable or decreasing slightly in the other countries shown in the bottom two panels. The countries in the bottom two panels do not have significant changes over time as shown by the US Hispanic females in the last row of Table 1 (results for the other countries not shown). The male and female populations with the highest incidences in countries (populations) with increasing incidences of all sites but skin cancer over time are the US (blacks $>$ whites $>$ Hispanic males only), Australia, New Zealand, Canada, Spain, Europe, Israel, and Japan. The male and female populations of countries with stable incidences of all sites but skin cancer over time are Italy, Africa, and South America, and those with slightly decreasing incidences are China, Thailand, and India.

Note that males always have noticeably higher incidences than females but only in the developed countries with primarily European-ancestry populations that have increasing incidences over time, not in the developing countries with other ancestry populations that have stable or decreasing incidences (compare the males in the left panels with the females in the right panels). The only exception is the US Hispanics that have males with higher incidences that are increasing over time (left middle panel), while the females have lower incidences that are not increasing over time (right bottom panel and see Table 1 for insignificant Hispanic Females $p$ value). Black males have the highest incidence of all sites but skin cancer followed by white (left top panel) and Hispanic males (left middle panel) in the US. Although Africa has a black population, it has a mixture of other populations that include but are not limited to Arabs, Egyptians, Berbers, Moors, Mulatoes, Bantu, Semitic, and many others. ${ }^{[59]}$ Statistical analysis reveals all the males and females in the countries displayed in the top four panels of Figure 1 have significant increases over increasing time, except the males and females in Italy (see Table 1).

Table 1. The significance of increasing cancer incidence over time for males and females from 1965 to 2005 in various countries around the world shown in the top four panels of Figure 1; including one example $p$ value for US Hispanic females from the bottom two panels showing no significance

\begin{tabular}{lll}
\hline Country/Gender & $\boldsymbol{R}^{2}$ & $\boldsymbol{p}$ values \\
\hline US Black males & 0.776 & .00385 \\
US White males & 0.908 & $2.06 \times 10^{-5}$ \\
Australia males & 0.921 & $6.23 \times 10^{-4}$ \\
New Zealand males & 0.931 & $4.34 \times 10^{-4}$ \\
Canada males & 0.973 & $1.52 \times 10^{-7}$ \\
US White females & 0.926 & $8.62 \times 10^{-6}$ \\
US Black females & 0.894 & $3.86 \times 10^{-4}$ \\
New Zealand females & 0.839 & .00374 \\
Australia females & 0.937 & $3.47 \times 10^{-4}$ \\
Canada females & 0.972 & $1.76 \times 10^{-7}$ \\
Italy males & 0.464 & .0920 \\
Spain males & 0.988 & $5.55 \times 10^{-7}$ \\
Europe males & 0.982 & $2.70 \times 10^{-8}$ \\
Israel males & 0.865 & $2.74 \times 10^{-4}$ \\
Japan males & 0.921 & $1.12 \times 10^{-5}$ \\
US Hispanic males & 0.851 & $4.00 \times 10^{-4}$ \\
Israel Females & 0.792 & .00129 \\
Italy Females & 0.189 & .330 \\
Europe Females & 0.952 & $1.50 \times 10^{-6}$ \\
Spain Females & 0.937 & $8.08 \times 10^{-5}$ \\
Japan Females & 0.857 & $1.23 \times 10^{-4}$ \\
US Hispanic Females & 0.134 & .332 \\
\hline
\end{tabular}

Then we analyzed the worlds' top cancer incidences of males and females to know if the cancers with some of the highest incidences in males and females, i.e., breast, prostate and colon, are responsible for the observed increasing trend over time. Because we found all cancers but skin are increasing in people of European ancestry while they are stable or 
decreasing slightly in people of Asian ancestry like the eastern Indians, Chinese, and Thai, we analyzed people in New Zealand and compared their values to people in India. The incidence of breast cancer is significantly increasing over time for females in New Zealand (see Table 2) while it is stable over time for females in India (see Figure 2, top panel). Note that the incidence of male breast cancer is extremely rare and unnoticeable if all ages are analyzed ( $0-85+)$ because the primary incidence occurs over the age of 70 . The incidence of prostate cancer is significantly increasing over time for males in New Zealand (see Table 2), while it is decreasing slightly over time for males in India (see Figure 2, middle panel). The incidence of colon cancer is increasing slightly, but not significantly (see Table 2), over time for males and females in New Zealand and is decreasing slightly over time
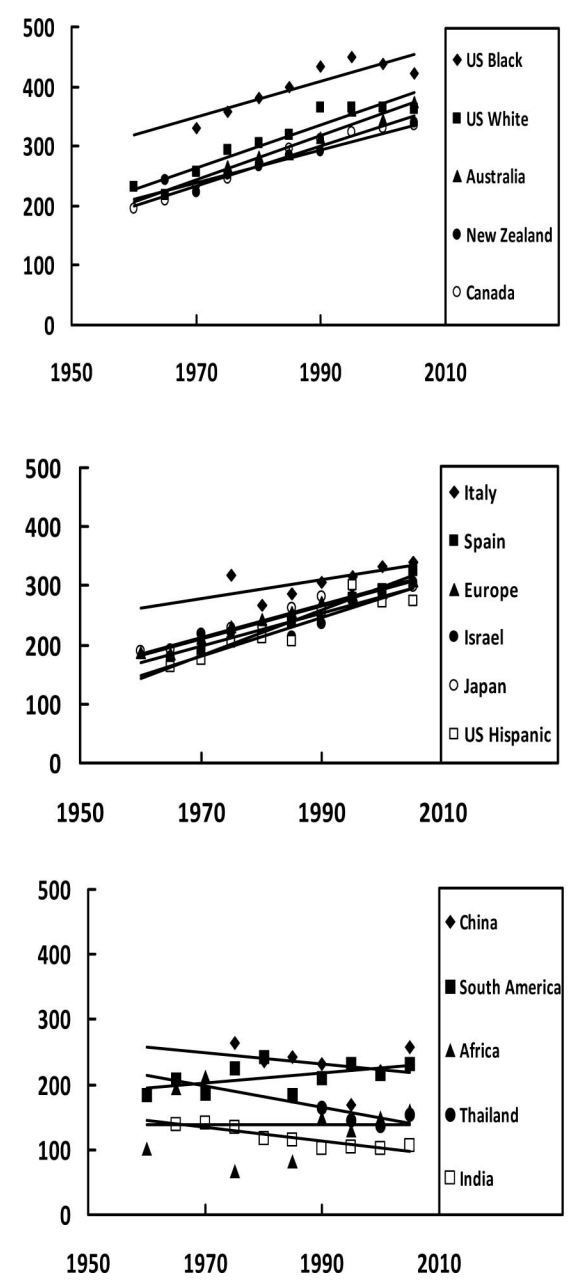

for males and females in India (see Figure 2, bottom panel). Table 2 shows only the New Zealand female breast and male prostate cancers are significantly increasing over time, while colon cancer is not. Moreover, no significant increase occurs with Indian female breast cancer or either Indian or New Zealand male or female colon cancer. The incidence of colon cancer is significantly decreasing in the Asian-ancestry population of eastern Indians and may reflect their preference for spices like turmeric, which is known to be an anti-cancer agent. Breast, prostate, and colon cancers comprise $\geq 25 \%$ of all sites but skin cancer and are apparently helping to drive the upward trend over time in developed countries with primarily European-ancestry populations. We also saw significant increases in male and female thyroid and liver cancer incidences in the US (results not shown).
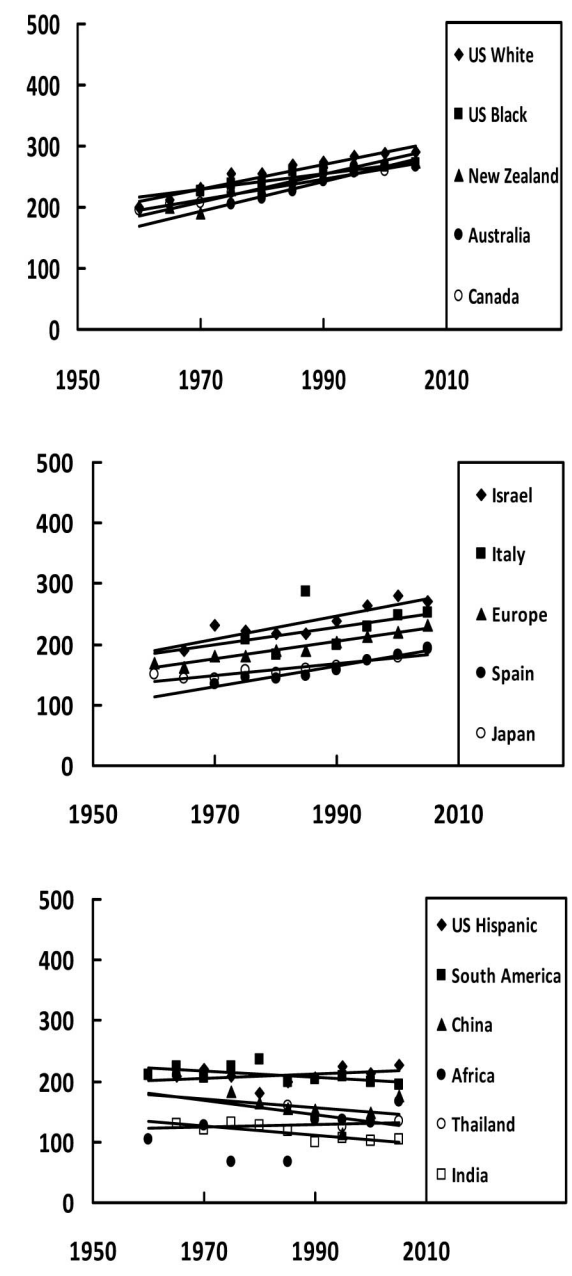

Figure 1. Age-standardized incidences of all sites but skin cancer cases per 100,000 people over time (1965-2005) for males and females $0-85+$ years old in various countries around the world whose people have primarily Fitzpatrick skin type I-III (white), III-IV (Asian and Hispanic), IV-V (Italian, Israeli, Indian) and V-VI (blacks). Top left panel (males): US Black, US White, Australia, New Zealand, and Canada. Top right panel (females): US White, US Black, New Zealand, Australia, and Canada. Middle left panel (males): Italy, Spain, Europe, Israel, Japan, and US Hispanic. Middle right panel (females): Israel, Italy, Europe Spain, and Japan. Bottom left panel (males): China, South America, Africa, Thailand, and India. Bottom right panel (females): US Hispanic, South America, China, Africa, Thailand, and India. 
Table 2. $P$ values for the incidence of male and female colon, breast, and prostate cancers over time (1965-2005) in New Zealand (European Ancestry) and India (Asian Ancestry)

\begin{tabular}{|c|c|c|c|c|}
\hline & $R^{2}$ & $p$ Values & Slope & Comments \\
\hline \multicolumn{5}{|c|}{ Breast cancer incidence over time } \\
\hline NZ Females & 0.924 & $3.72 \times 10^{-5}$ & 0.950 & Pos. Slope $* * *$ \\
\hline Indian Females & 0.413 & .0619 & 0.0859 & Pos. Slope NS \\
\hline NZ Males & 0.336 & .102 & 0.0039 & Pos. Slope NS \\
\hline Indian Males & 0.718 & .00394 & 0.0024 & Pos. Slope $* *$ \\
\hline \multicolumn{5}{|c|}{ Prostate cancer incidence over time } \\
\hline NZ Males & 0.689 & .00560 & 1.87 & Pos. Slope * \\
\hline Indian Males & 0.434 & .0534 & -0.0546 & Neg. Slope NS \\
\hline \multicolumn{5}{|c|}{ Colon cancer incidence over time } \\
\hline NZ Male & 0.505 & .0320 & 0.160 & Pos. Slope * \\
\hline NZ Female & 0.163 & .281 & 0.0687 & Pos. Slope NS \\
\hline India Male & 0.609 & .0131 & -0.0515 & Neg. Slope * \\
\hline India Female & 0.613 & .0126 & -0.0428 & Neg. Slope * \\
\hline
\end{tabular}

${ }^{*} p<.05 ; * * p<.005 ; * * *<.0005$; NS: not significant; Pos. Slope: positive slope or incidence increases over time; Neg. Slope: negative slope or incidence decreases over time.
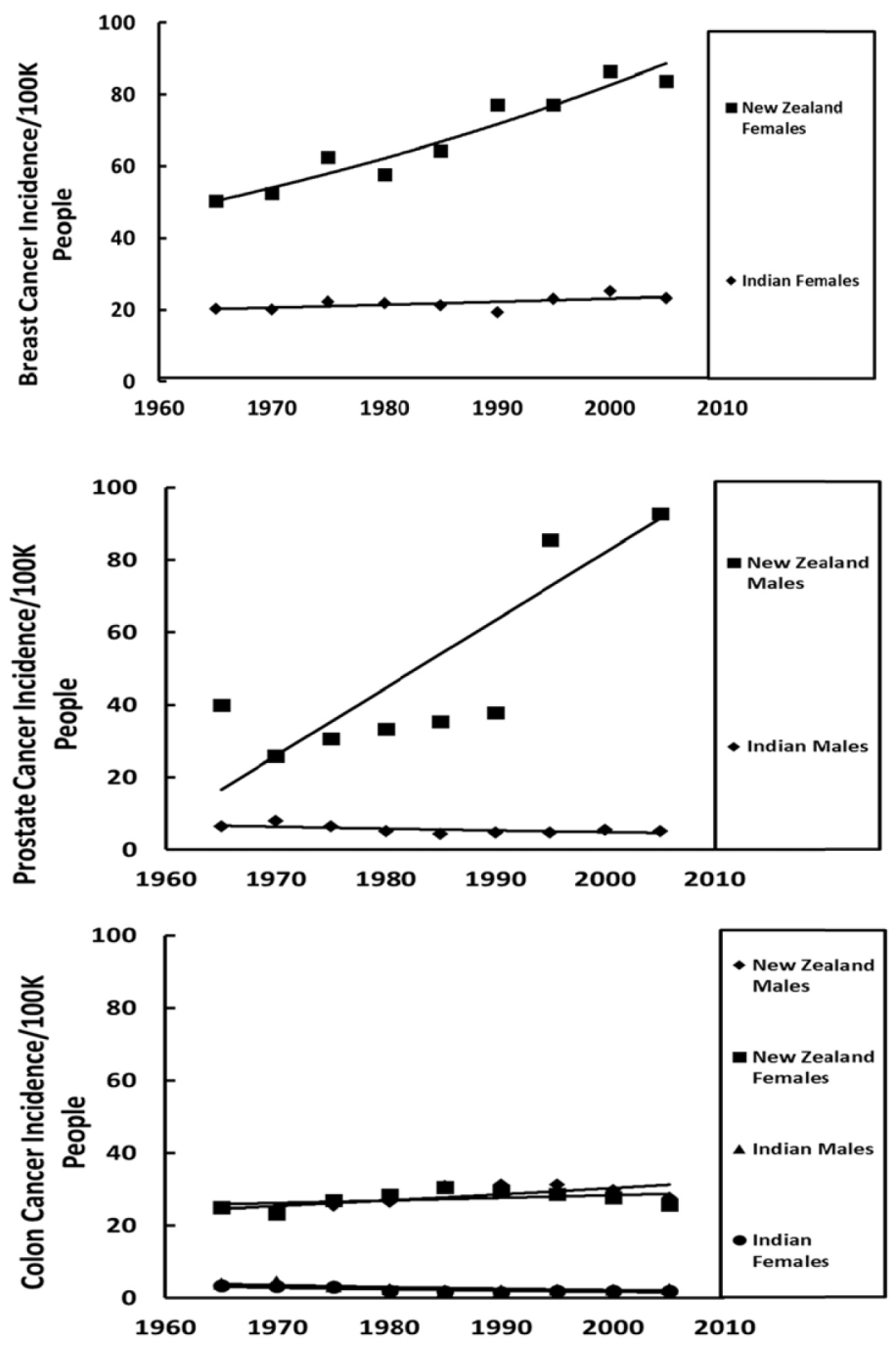

Figure 2. Age-standardized incidences of breast, prostate, and colon per 100,000 people over time (1965-2005) for males and females 0-85+ years old in New Zealand (NZ) with primarily European-ancestry Fitzpatrick skin type I-III (white) or India with primarily Asian-ancestry Fitzpatrick skin IV-V (brown). Note that the European-ancestry cancer incidences are always higher than the Asian-ancestry cancer incidences. 
We further analyzed the populations of the countries by five age groups $(0-14,15-29,30-49,50-69$ and 70-85+) over time and over UVB dose (unpublished results). We observed a significant increase only in the oldest age group (70-85+) between the incidence of all sites but skin cancer and time for European ancestry populations. In addition, we also observed a decrease in the incidence of all sites but skin cancer with increasing UVB dose but only for people in developed countries with primarily European ancestry. Moreover, we observed a significant correlation between decreasing cancer incidence and increasing UVB dose for Thai and Indian females in the next oldest age group (50-69) and an opposite correlation for African males and females, or decreasing cancer incidence with decreasing UVB dose (results not shown).

To learn how cancer changes over the advancing age of males and females around the world, we analyzed the populations of most of the countries that have increasing incidences over time (see Table 3) and compared them to populations of most of the countries that have stable or slightly decreasing incidences over time (see Table 3) and depicted the results in Figure 3A and B, respectively. We observe a noticeable increase in the female incidence of all cancers but skin between the ages of 20 and $40 \mathrm{yrs}$. compared to the males in the same age range (see Figure 3A) but only when the incidence increases over time (see Table 3). Although slightly higher for females, the all sites but skin cancer incidence does not noticeably differ between the sexes when the incidence is stable or decreasing over time (see Figure 3B). Table 3 shows that females between 20 and 49 yrs. of age have almost twice the incidence as males, while males have almost twice the incidences as females over the age of 49 . The incidence of all sites but skin cancer increases with age independent of sex or ethnicity and whether or not the incidence is increasing (see Table 3) or stable/decreasing (see Table 3) over time.

Table 3. All sites but skin cancer incidences for the five age groups used in the UVB dose analysis; top portion is for the four panels of Figure 1 with increasing cancer incidences over time (also plotted by age group in the top panels of Figure 3); bottom portion is the bottom two panels of Figure 1 with stable or decreasing cancer incidences over time (also plotted by age group in the bottom panels of Figure 3)

\begin{tabular}{lllllllllll}
\hline Age group & $\mathbf{0 - 1 4}$ & $\mathbf{0 - 1 4}$ & $\mathbf{1 5}-\mathbf{2 9}$ & $\mathbf{1 5 - 2 9}$ & $\mathbf{3 0 - 4 9}$ & $\mathbf{3 0 - 4 9}$ & $\mathbf{5 0 - 6 9}$ & $\mathbf{5 0 - 6 9}$ & $\mathbf{7 0 - 8 5 +}$ & $\mathbf{7 0 - 8 5 +}$ \\
\hline Gender & Males & Females & Males & Females & Males & Females & Males & Females & Males & Females \\
\hline Country & & & & & & & & & & \\
\hline US (Blacks) & 14 & 13 & 25 & 33 & 156 & 233 & 1,441 & 892 & 3,008 & 1,651 \\
US (Whites) & 17 & 15 & 35 & 42 & 149 & 250 & 1,217 & 901 & 2,949 & 1,740 \\
Australia & 16 & 14 & 40 & 38 & 160 & 243 & 1,195 & 825 & 3,183 & 1,604 \\
Italy & 18 & 15 & 41 & 42 & 138 & 247 & 1,087 & 767 & 2,920 & 1,375 \\
US (Hispanics) & 16 & 14 & 30 & 30 & 107 & 203 & 913 & 698 & 2,274 & 1,386 \\
Average & 16 & 14 & 34 & 37 & 142 & 235 & 1,170 & 816 & 2,867 & 1,551 \\
China & 11 & 8 & 16 & 18 & 128 & 148 & 837 & 562 & 2,125 & 1,078 \\
South America & 15 & 12 & 26 & 27 & 92 & 183 & 712 & 579 & 2,129 & 1,161 \\
Thailand & 12 & 9 & 17 & 22 & 89 & 146 & 488 & 405 & 1,173 & 678 \\
Africa & 19 & 13 & 25 & 31 & 127 & 197 & 454 & 498 & 1,120 & 673 \\
India & 9 & 6 & 12 & 14 & 65 & 108 & 358 & 346 & 676 & 446 \\
Average & 13 & 10 & 19 & 22 & 100 & 156 & 570 & 478 & 1,445 & 807 \\
\hline
\end{tabular}

Because we found US blacks have a higher incidence of all sites but skin cancer than US whites have (see Figure 1) and they are reported to have higher estrogen but not testosterone levels, ${ }^{[60]}$ we analyzed male breast cancer that has the highest, and most reliable, incidences in the oldest age group (70-85+) as an indicator of estrogen levels in men (see Figure 4A, B and C). We did this because, similar to females, male breast cancer incidence is also dependent on estrogen; ${ }^{[22]}$ to increase reliability of this rarely occurring cancer in men we used the oldest age group because they have the highest incidences. We found the incidence of male breast cancer was highest in US blacks (9.8) and Israelis (10.8) followed by Africans (7) and US whites (6.4) followed by Canadians (6). The incidence of breast cancer, and presumably levels of estrogen in males shown in Figure 4A, B, and C correlates fairly well with the male incidences of all sites but skin cancer shown in Figure 1. Blacks in the US have a higher incidence of male breast cancer than US whites (and Canadians), which correlates well with the incidences of all sites but skin cancer in males, except Australia and New Zealand that 
appear to be somewhat lower than we would predict based on the results in Figure 1. The incidence of male breast cancer shown in Figure 4B correlates well with those shown in the middle two panels of Figure 1 except Israel (10.8) which is somewhat higher than predicted, while Japan (2.1) and Hispanics in the US (3.3) are lower than predicted based on their incidences of all sites but skin cancer. The incidences of male breast cancer in Figure 4C correlates well with the incidence of all sites but skin cancer shown in the bottom two panels of Figure 1, except Africans (7) appear higher than predicted. The incidence of breast cancer in older females (70-85+) shown in Figure 4D, E and F correlates extremely well with the incidence of all sites but skin cancer for females shown in Figure 1 except for the slightly higher levels in Canada (see Figure 4E).

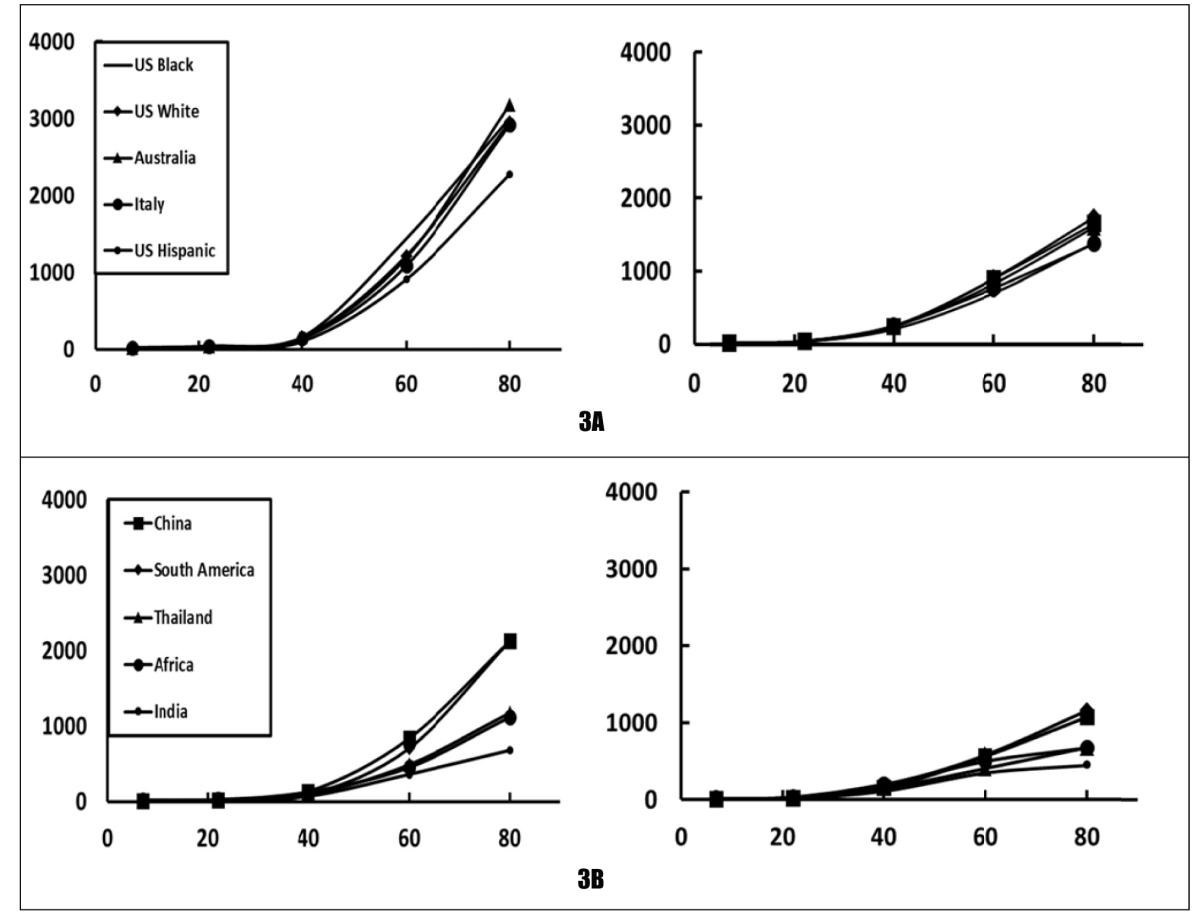

Figure 3. Cancer incidence over the advancing age of the individual in 2005 (males on left, females on right): A) from Figure 1's Top and Middle Panels with increasing incidences over time (see Table 3A); B) from Figure 1's Bottom Panels with Stable or Decreasing incidences over time.
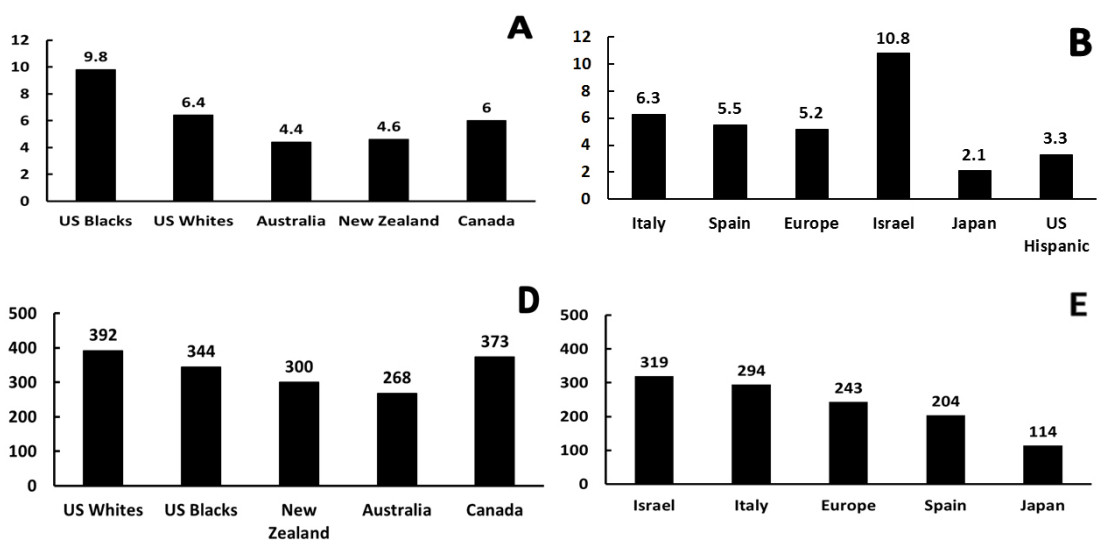

D

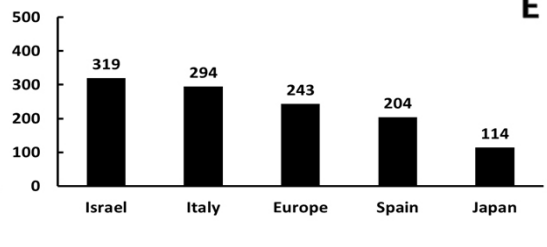

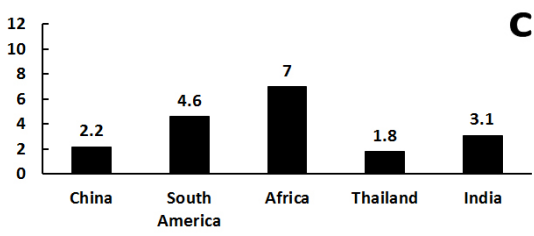

C

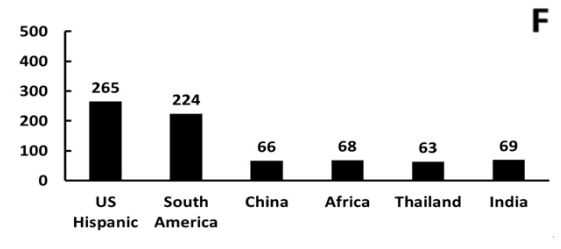

Figure 4. Age-standardized incidences in 2005 of male and female breast cancer cases for 70-85+ age group per 100,000 people as an indicator of estrogen levels of the different skin types around the world according to IARC data. Males: A) US Blacks, US Whites, Australia, New Zealand, Canadian; B) Italy, Spain, Europe, Israel, Japan, US Hispanics; C) China, South America, Africa, Thailand, India. Females: D) US Whites, US Blacks, New Zealand, Australia, Canada; E) Israel, Italy, Europe, Spain, Japan; F) US Hispanic, South America, China, Africa, Thailand, India. 
To know if vitamin $\mathrm{D}_{3}$ plays a role in developed countries with European-ancestry populations (indoor workers), we analyzed breast, prostate and colon cancers over UVB dose for white and black males and females in the US (2005). The incidence of breast (see Table 4, Figure 5A, top panels), prostate (see Table 4, Figure 5A bottom panels), and colon (see Table 4C, Figure 5B) cancers all significantly decrease with increasing UVB dose (negative slope) exclusively in the oldest white population (70-85+). Additionally, breast and prostate cancers, but not colon, have significant decreases with increasing UVB dose (negative slope) in the next oldest age group (50-69), and female breast cancer is also significant in the middle-aged, age group (30-49; negative slope). Note that only the US white, but not the black, population has significant decreases in their cancer incidences with increasing UVB. Because we only see a significant effect in whites and not in blacks, a clear UVB effect is evident because the melanin in the black skin absorbs the UVB impeding its' penetration and consequently the biological effects. This significance in the oldest age group of whites but not blacks may be due to the white population's higher vitamin $\mathrm{D}_{3}$ status and consequent better immune response.

Table 4. Breast, Prostate and Colon cancer incidence of white and black females in the US (2005) for the older age groups, $30-49,50-69$ and $70-85+$

\begin{tabular}{|c|c|c|c|c|c|}
\hline & Age Group & $R^{2}$ & $p$ Values & Slope & Comments \\
\hline \multirow{3}{*}{ White Female Breast } & $30-49$ & 0.207 & .015 & -.00299 & Neg. Slope * \\
\hline & $50-69$ & 0.203 & .016 & -0.00555 & Neg. Slope * \\
\hline & $70-85+$ & 0.492 & $3.2 \times 10^{-7}$ & -0.0153 & Neg. Slope $* * *$ \\
\hline \multirow{3}{*}{ Black Female Breast } & $30-49$ & 0.069 & .168 & 0.00235 & Pos. Slope NS \\
\hline & $50-69$ & 0.001 & .882 & 0.00056 & Pos. Slope NS \\
\hline & $70-85+$ & 0.025 & .415 & -0.0050 & Neg. Slope NS \\
\hline \multirow{3}{*}{ White Male Prostate } & $30-49$ & 0.05 & .146 & -0.0003 & Neg. Slope NS \\
\hline & $50-69$ & 0.278 & $2.37 \times 10^{-4}$ & -0.0162 & Neg. Slope $* * *$ \\
\hline & $70-85+$ & 0.416 & $9.10 \times 10^{-4}$ & -0.0300 & Neg. Slope $* * *$ \\
\hline \multirow{3}{*}{ Black Male Prostate } & $30-49$ & 0.127 & .058 & -0.0018 & Neg. Slope NS \\
\hline & $50-69$ & 0.015 & .530 & -0.0086 & Neg. Slope NS \\
\hline & $70-85+$ & 0.001 & .584 & 0.0141 & Pos. Slope NS \\
\hline \multirow{3}{*}{ White Female Colon } & $30-49$ & 0.074 & .041 & 0.000190 & Pos. Slope $*$ \\
\hline & $50-69$ & 0.050 & .246 & 0.000786 & Pos. Slope NS \\
\hline & $70-85+$ & 0.613 & $5.17 \times 10^{-7}$ & -0.0131 & Neg. Slope $* * *$ \\
\hline \multirow{3}{*}{ Black Female Colon } & $30-49$ & 0.145 & .042 & 0.000404 & Pos. Slope * \\
\hline & $50-69$ & 0.050 & .241 & 0.00161 & Pos. Slope NS \\
\hline & $70-85+$ & 0.008 & .635 & -0.00280 & Neg. Slope NS \\
\hline \multirow{3}{*}{ White Male Colon } & $30-49$ & 0.166 & .028 & 0.000396 & Pos. Slope * \\
\hline & $50-69$ & 0.104 & .089 & 0.00189 & Pos. Slope NS \\
\hline & $70-85+$ & 0.273 & .0037 & -0.00979 & Neg. Slope $* *$ \\
\hline \multirow{3}{*}{ Black Male Colon } & $30-49$ & 0.168 & .027 & 0.00101 & Pos. Slope * \\
\hline & $50-69$ & 0.097 & .100 & 0.00462 & Pos. Slope NS \\
\hline & $70-85+$ & 0.000 & .982 & -0.000149 & Neg. Slope NS \\
\hline
\end{tabular}

${ }^{*} p<.05 ;{ }^{* *} p<.005 ; * * * p<.0005$; NS: not significant; Pos. Slope: positive slope or incidence increases with increasing UV; Neg. Slope: negative slope or incidence decreases with increasing UV.

\section{DISCUSSION}

The data suggests the major carcinogenic drivers in many cancers are estrogen, increasing age (ROS), and decreasing vitamin $\mathrm{D}_{3}$ levels, which is due to more time spent indoors is responsible for the persistence of HPV infection in immune privileged androgenic hair follicles. The analysis reveals major differences in the temporal cancer incidence trends between developed countries (increasing steadily over time) with European ancestry populations and developing countries (stable to decreasing over time) with other ancestry populations regardless of skin type. This may reflect persistent HPV infection of immune-privileged androgenic body hair because European-ancestry populations have significantly more than Asian-ancestry populations. ${ }^{[51]} \mathrm{HPV}$ is activated 
by ROS, ${ }^{[16]}$ which can be produced during pheomelanin syn- virions systemically fueling carcinogenic events in distant thesis in red and blond hair, unlike eumelanin synthesis in sites. Only people of European ancestry have pheomelanin black hair, or irradiation with UVA, or visible light down synthesis and they also have the most androgenic hair where the hair shaft of white hair, may cause excessive release of HPV can hide and be stimulated by estrogen.

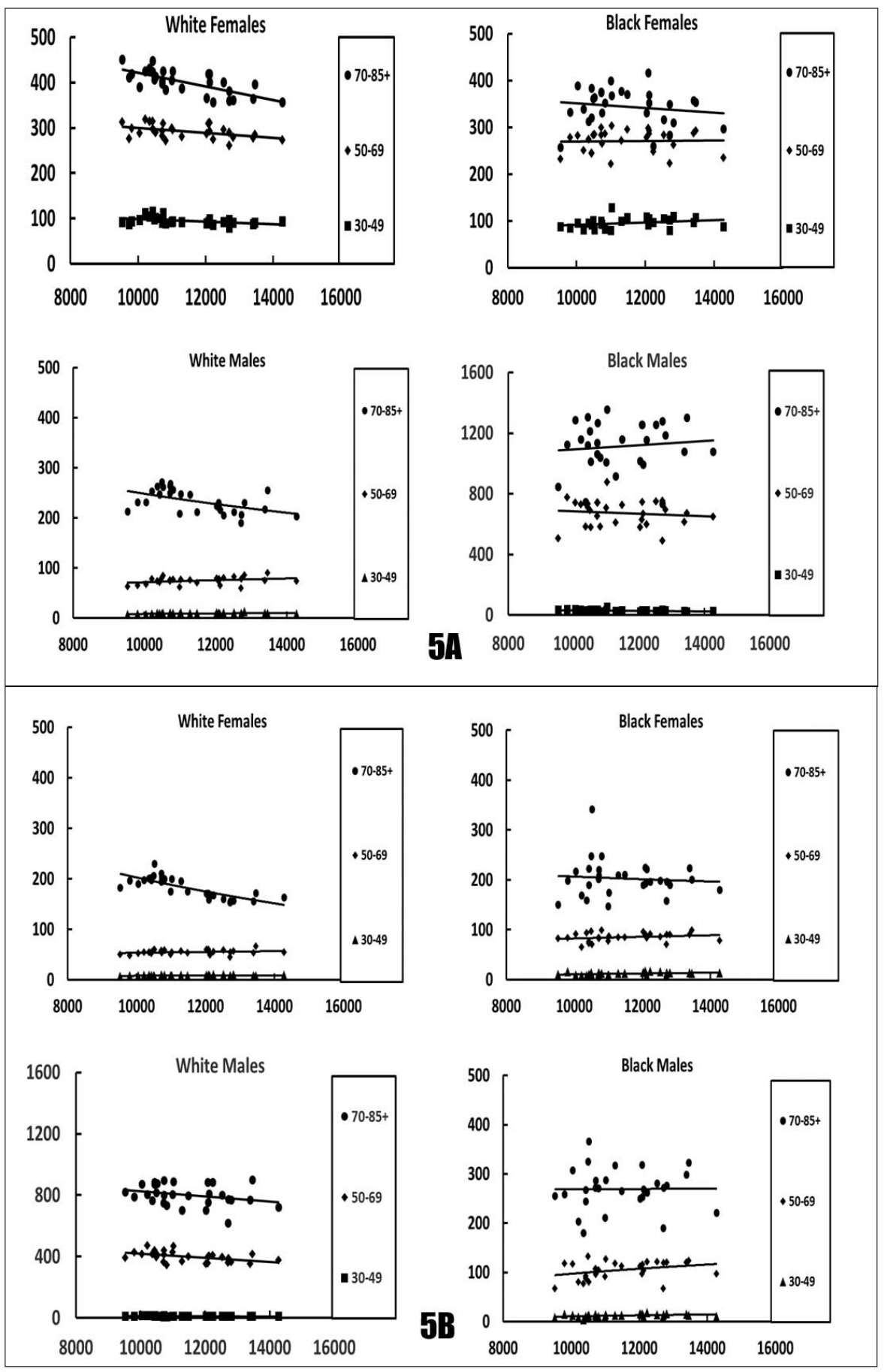

Figure 5. Age-standardized incidences in 2005 of breast, prostate and colon cancer cases per 100,000 people by age group (15-29, 30-49, 50-69, and 70-85+) and skin color over UVB dose in the US: A) female white and black breast cancer (top two panels) and male white and black prostate cancer (bottom two panels); B) female white and black colon cancer (top two panels) and male white and black colon cancer (bottom two panels). Note that we omitted the 0-14 yr. and 15-29 age group's data because most of the values were either zero or close to it. 
We obtained the first line of evidence that estrogen plays a major role in all cancers from US black males who have a significantly higher incidence of all cancers (but skin) than US white males, which are steadily increasing over time (see Figure 1), because they are known to have significantly higher estrogen levels than white males. ${ }^{[60]}$ We found more evidence supporting a role for estrogen in all cancers by comparing male and female incidences especially between the ages of 20 and 40. We found females, who have higher estrogen levels than males during that time of life, have noticeably higher incidences of all cancers than males, particularly in developed countries with European ancestry (see Figure 3A and Table 3). That data also shows males have much higher incidences than females over the age of 49 when they have 2-3 times higher estrogen levels than females. ${ }^{[61]}$ Unlike females whose estrogen levels decrease with age, male's estrogen levels increase with age, which may explain why they have significantly higher cancer incidences over age 69 (see Figures 3, 5, and 6). Further evidence suggesting estrogen is involved in many cancers can be seen in Figures 4A-C, where male breast cancer serving as an indicator of estrogen levels in men, ${ }^{[22]}$ displays very good agreement with the incidence levels of all sites but skin cancer seen in Figure 1. The incidence of female breast cancer is in excellent agreement with their incidences of all sites but skin cancer. Moreover, the observed seasonality of many cancers ${ }^{[62-67]}$ might reflect the hormonal seasonal fluctuations of estrogen. ${ }^{[68,69]}$ Thus, our findings add epidemiological support to the already existing biochemical evidence obtained from birth control pills and hormonal replacement therapy in females suggesting a carcinogenic role for estrogen ${ }^{[20]}$ in many cancers of both sexes.

If we assume estrogen levels have remained stable in all populations over time, then it is not the reason why cancers have been steadily increasing over recent decades (see Figure 1). To know if the top occurring cancers are all increasing over time or which of those might be contributing toward the steady increase; we analyzed some of the highest occurring cancer incidences in both males and females: breast, prostate, and colon cancers (see Figure 2). We found only the cancer incidences in developed countries primarily of European ancestry (see Figure 1), as noted by the New Zealand profiles compared to the developing country with eastern Indian profiles, are steadily increasing over time and they are also affected by vitamin $\mathrm{D}_{3}$ (breast and prostate). ${ }^{[15]}$ However, when we analyzed all cancer incidences over UVB dose, we did not find significant support for a role for vitamin $\mathrm{D}$ because the slope of the line was not significant with UVB dose for most age groups except the oldest (results not shown). While almost 20 cancers appear to decrease

Published by Sciedu Press with decreasing UVB dose or increasing vitamin D levels, ${ }^{[15]}$ some cancers increase with increasing $\mathrm{UVB}^{[12]}$ so that a mixture of these cancers might obscure a relationship with UVB dose. For example, the incidence of cervical or pharyngeal cancers increase with increasing UVB dose in the US only in whites, and not blacks, presumably from inflammatory cytokine production and the fact that these cells apparently lack the vitamin D receptor and corresponding apoptotic mechanism. ${ }^{[12]}$

Conversely, the incidence of cutaneous malignant melanoma increases with decreasing UVB dose in Europe, especially in Italy, and these cells have the vitamin D receptor. ${ }^{[52]}$ Melanoma is an excellent example of a cancer that shows increasing incidence with decreasing UVB dose (and presumably decreasing vitamin D levels), especially after 1960. Other cancers reported to increase with decreasing UVB are lung, gastric, liver, colon, breast, prostate, endometrial, esophageal, bladder, head and neck, leukemia, ovarian, pancreatic, pleura, rectal, thyroid, and non-Hodgkin's lymphoma. ${ }^{[15]}$ We found breast, prostate and colon cancers decrease with increasing UVB dose (or increasing latitude), which agrees with others who found breast, ${ }^{[70]}$ prostate $^{[71]}$ and colon ${ }^{[72]}$ cancers decrease with increasing UVB dose, ${ }^{[73]}$ decreasing latitude ${ }^{[74]}$ or increasing vitamin $\mathrm{D}_{3} .{ }^{[75]}$ We expanded on those findings by analyzing the different skin types in five age groups to find only the whites, but not the blacks, oldest age group (70-85+) have significant negative slopes. This indicates increasing UVB significantly decreases the incidences of breast, prostate, and colon cancers presumably from increasing levels of vitamin $\mathrm{D}_{3}$ and its positive effects on biological systems like the immune response, gene regulation, and inducing apoptosis of damaged cells.

So why have cancer rates been increasing steadily over time only in developed countries? Some scientists think the increasing incidence over time of all sites but skin cancer in developed countries is due to increasing life expectancy, red meat consumption, obesity, or exposure to chemical pollutants. However, the increasing life expectancy in Japan has outpaced the US since 1965 while their all sites but skin cancer rates have been lower than the US over recent decades (see Figure 1). Moreover, China also had a steady increase in their life expectancy since $1965^{[76]}$ but their all sites but skin cancer rates have been decreasing over time (see Figure 1). Possibly the increasing consumption of red meat over time might explain the increase in the incidence of cancer, but Japan and China have about the same low level red meat consumption (about half the US) while the former has increasing and the latter has decreasing cancer rates over time. ${ }^{[77]}$ Next the increasing obesity levels in developed and lately developing countries also does not explain the increas- 
ing incidence of cancers over time because the rates of type 2 diabetes, an indicator of obesity, has increased dramatically (about tenfold) in China from 1980 to $2008^{[78]}$ while their all sites but skin cancer levels have steadily declined during that time frame (see Figure 1). Finally, increasing exposure to industrialized pollutants are apparently not major carcinogenic drivers because we observe an increasing incidence of all cancers with increasing age in all countries worldwide regardless if they are developed or developing (see Figure $3 \mathrm{~A}$ and $\mathrm{B}$ and Table 3 ). Thus, increasing life expectancy, red meat consumption, obesity, or exposure to industrialized chemical pollutants does not explain the steadily increasing incidence of all sites but skin cancer over recent decades.

One reasonable explanation for the steadily increasing incidences of all sites but skin cancer over time in primarily developed countries might be because these countries have European ancestry populations with the most androgenic body hair to harbor HPV. ${ }^{[51]}$ European ancestry populations increased indoor work and sun protection behaviors over recent decades resulting in decreasing vitamin $\mathrm{D}_{3}$ levels, as noted by the steady increase in its inversely related parathyroid hormone. ${ }^{[55]}$ We know low levels of vitamin $\mathrm{D}_{3}$ fuel persistent HPV infection ${ }^{[79]}$ that has been steadily increasing over recent decades in developed countries in Europe ${ }^{[53]}$ and in the US. ${ }^{[7]}$ Moreover, all cancer incidences probably increase over the advancing age of the individual because their ability to make vitamin $D_{3}$ decreases with increasing age due to thinning of the epidermis ${ }^{[80]}$ and exposure to higher ROS levels, as shown by the shutdown of melanin synthesis in hair turning it white. ${ }^{[81]}$ Decreasing vitamin $\mathrm{D}_{3}$ levels and increasing ROS with advancing age along with male estrogen levels that are 2-3 times higher than females over the age of 49 might explain why all cancer incidences increase with increasing age and steadily increase with advancing age of males (see Figures $3 \mathrm{~A}$ and $3 \mathrm{~B}$ and values in Table $3)$. Intriguingly, lower levels of vitamin D lead to higher levels of estrogen in a dose dependent manner, ${ }^{[82]}$ so that estrogen might have actually been slowly increasing over recent decades in only developed countries where most people work indoors. Lower cancer incidences in Asians and other populations compared to European populations might be from outdoor work leading to good vitamin $\mathrm{D}_{3}$ levels and the fact that they primarily synthesize eumelanin (black hair), which absorbs ROS, rather than pheomelanin (red and blond hair) that produces ROS, so that ROS do not activate HPV and cause increased release of its virions.

Estrogen combined with ROS synergistically increases the incidence of cancer ${ }^{[19]}$ and synergizes with HPV ${ }^{[83]}$ Estrogen is responsible for the onset, persistence, and malignant transformation of cervical cells ${ }^{[84]}$ by stimulating oncogenic expression of HPV's E6 and E7 proteins promoting viral proliferation $^{[17]}$ and driving cells through the cell cycle. ${ }^{[85]}$ Additionally, ROS activates HPV ${ }^{[16]}$ and its E6 protein can in turn cause production of more ROS and DNA damage. ${ }^{[86]}$ The E2 protein of HPV also results in production of ROS by interacting with the cells' mitochondria ${ }^{[87]}$ creating oxidized cytosines that can spontaneously deaminate and become thymines. Cytosine to thymine transition mutations can also occur via viral activation of the APOBEC system resulting in epigenetic methylation and deamination of cytosines. These epigenetic methylations are predominately at $\mathrm{NpCpG}$ trinucleotide sites and are signature mutations of most cancers. ${ }^{[29]}$ APOBEC3B-mediated cytosine deaminations creating $\mathrm{C} \rightarrow \mathrm{T}$ (or $\mathrm{G}$ ) mutations in phosphatidylinositol 3-kinase catalytic subunit, PIK3CA, are specific for $\mathrm{HPV}+$ tumors, as they are not associated with Hepatitis $\mathrm{B}$ or C liver cancers or HPV- oropharyngeal cancer and are only found in cervical and HPV+ oropharyngeal cancers. ${ }^{[30]}$ PIK3CA mutations are found in a variety of human malignancies, ${ }^{[88]}$ adding more evidence that HPV probably causes many cancers. In addition, transition mutations $\mathrm{C} \rightarrow \mathrm{T}$ (or G) in CDKN2A, a gene that codes for p16 and p14arf tumor suppressor proteins are exclusive to HPV+ oropharyngeal and cervical cancers. ${ }^{[89,90]}$ Intriguingly, many soft tissue tumors have an amplicon from host genomic DNA that HPV presumably deleted upon integration into chromosome $12 q(12 q 13-15) .{ }^{[91]}$ In this section of chromosome $12 q$, many genes related to both cancer and HPV infection are found: AID (12q13), APOBEC1 (12q13.1), ${ }^{[26]}$ the vitamin D receptor (12q13.11), CDK4 (cyclin-dependent kinases), MDM2 (murine double minutes), SAS (sarcoma amplified sequence), ${ }^{[26,92]}$ HMGI-C (high mobility glycoprotein), GLI (Glioblastoma), CHOP(C/EBP Homologue Protein), OS4, and OS9. ${ }^{93]}$ The vitamin $\mathrm{D}$ receptor has a large $\mathrm{CpG}$ island in its promoter region so that it can be silenced by methylation, which is important because it interacts with coactivator and cosuppressor proteins that are in contact with chromatin modifiers and remodelers and it also has certain ligands that have DNA demethylating effects. ${ }^{[94]}$ We can obtain convincing evidence of an anticancer role for vitamin $\mathrm{D}_{3}$ in humans from a recent vitamin $\mathrm{D}_{3}$, calcium randomized clinical trial using supplements, ${ }^{[95]}$ along with a pooled analysis of randomized trails, ${ }^{[96]}$ and a prospective cohort study ${ }^{[97]}$ because they showed significant reductions in their all-cancers risk. Intriguingly, Neanderthals gave some of the Europeans HPV16A, ${ }^{[98]}$ so that this ancestry population had a "head start" for increasing their incidences of cancer over recent decades from indoor work and decreasing levels of vitamin $\mathrm{D}_{3}$.

Apparently, the "perfect storm" for creating cancer involves 
high levels of estrogen, ROS (older age), and low vitamin $\mathrm{D}_{3}$ levels fueling persistent infection of immune-privileged androgenic body hair by HPV, which is activated by ROS (red and white hair) to release virions into the body increasing viral loads over the advancing age of the individual. ${ }^{[16]}$ Decreasing vitamin $\mathrm{D}_{3}$ levels over recent decades has decreased immune effectiveness ${ }^{[99-101]}$ fueling HPV persistence, which apparently contributes toward increasing the incidence of many cancers. Our results provide worldwide evidence that estrogen and old age (via ROS), rather than industrialized chemical pollutants, plays major roles in most cancers and suggests there may be even more HPV-related cancers than

\section{REFERENCES}

[1] Global Burden of Disease Cancer Collaboration., Fitzmaurice C, Allen C, Barber RM, Barregard L, Bhutta ZA, Brenner H, et al. Global, Regional, and National Cancer Incidence, Mortality, Years of Life Lost, Years Lived With Disability, and Disability-Adjusted Lifeyears for 32 Cancer Groups, 1990 to 2015: A Systematic Analysis for the Global Burden of Disease Study. JAMA Oncol. 2016.

[2] de Gruijl FR, Sterenborg HJ, Forbes PD, et al. Wavelength dependence of skin cancer induction by ultraviolet irradiation of albino hairless mice. Cancer Res. 1993; 53: 53-60.

[3] Key TJ, Appleby PN, Reeves GK, et al. for the Endogenous Hormones and Breast Cancer Collaborative Group. Circulating sex hormones and breast cancer risk factors in postmenopausal women: reanalysis of 13 studies. Br J Cancer. 2011; 105: 709-722. PMid:21772329 https://doi.org/10.1038/bjc.2011.254

[4] Zhang X, Tworoger SS, Eliassen AH, et al. Postmenopausal plasma sex hormone levels and breast cancer risk over 20 years of followup. Breast Cancer Res Treat. 2013; 137: 883-892. PMid:23283524 https ://doi.org/10.1007/s10549-012-2391-z

[5] Ford D, Easton DF, Stratton M, et al. Genetic heterogeneity and penetrance analysis of the BRCA1 and BRCA2 genes in breast cancer families. The Breast Cancer Linkage Consortium. Am J Hum Genet. 1998; 62: 676-689.

[6] Bosch FX, Manos MM, Muñoz N, et al. Prevalence of human papillomavirus in cervical cancer: a worldwide perspective. International biological study on cervical cancer (IBSCC) Study Group. J Natl Cancer Inst. 1995; 87: 796-802.

[7] Chaturvedi AK, Engels EA, Pfeiffer RM, et al. Human papillomavirus and rising oropharyngeal cancer incidence in the United States. J Clin Oncol. 2011; 29: 4294-4301. PMid:21969503 https : //doi.org/10.1200/JC0.2011.36.4596

[8] Kvam E, Tyrrell RM. Induction of oxidative DNA base damage in human skin cells by UV and near visible radiation. Carcinogenesis. 1997; 18: 2379-2384. PMid:9450485 https ://doi .org/10.109 $3 / \operatorname{carcin} / 18.12 .2379$

[9] Shimizu M, Gruz P, Kamiya H, et al. Efficient and erroneous incorporation of oxidized DNA precursors by human DNA polymerase eta. Biochemistry. 2007; 46: 5515-5522. PMid:17439242 https://doi.org/10.1021/bi062238r

[10] Cooke MS, Evans MD, Dizdaroglu M, et al. Oxidative DNA damage: mechanisms, mutation, and disease. FASEB J. 2003; 17: 1195-214. PMid:12832285 https://doi.org/10.1096/fj.02-0752rev

Published by Sciedu Press previously thought. Increasing vitamin $\mathrm{D}_{3}$ levels and getting the HPV vaccination may significantly decrease the incidence of cancer in future generations.

\section{ACKNOWLEDgeMENTS}

The authors would like to thank Madhan Subramanian, Arjun Swaminathan, and Daniel Silverstein for assisting with some analyses. This research did not receive any specific grant from funding agencies in the public, commercial, or not-for-profit sectors.

\section{Conflicts of InTEREST Disclosure}

The authors declare that they have no competing interests.
[11] Breger J, Baeva L, Agrawal A, et al. UVB-induced inflammatory cytokine release, DNA damage and apoptosis of human oral compared with skin tissue equivalents. Photochem Photobiol. 2013; 89: 665670. PMid:23253030 https://doi .org/10.1111/php. 12030

[12] Godar DE, Tang R, Merrill SJ. Pharyngeal and cervical cancer incidences significantly correlate with personal UV doses among whites in the United States. Anticancer Res. 2014; 34: 4993-4999.

[13] Coussens LM, Werb Z. Inflammation and cancer. Nature. 2002; 420: 860-867. PMid:12490959 https://doi.org/10.1038/na ture 01322

[14] MacLaughlin JA, Anderson RR, Holick MF. Spectral character of sunlight modulates photosynthesis of previtamin D3 and its photoisomers in human skin. Science. 1982; 216: 1001-1003. https: //doi.org/10.1126/science.6281884

[15] Moukayed M, Grant WB. Molecular link between vitamin D and cancer prevention. Nutrients. 2013; 5: 3993-4021. PMid:24084056 https://doi.org/10.3390/nu5103993

[16] De Marco F. Oxidative Stress and HPV Carcinogenesis. Viruses. 2013; 5: 708-731. PMid:23403708 https://doi.org/10.3390/ v5020708

[17] Au WW, Abdou-Salama S, Al-Hendy A. Inhibition of growth of cervical cancer cells using a dominant negative estrogen receptor gene. Gynecol Oncol. 2007; 104: 276-280. PMid:17137618 https://doi.org/10.1016/j.ygyno.2006.10.015

[18] Le Poole IC, van den Berg FM, van den Wijngaard RM, et al. Generation of a human melanocyte cell line by introduction of HPV16 E6 and E7 genes. In Vitro Cell Dev Biol Anim. 1997; 33: 4249. PMid:9028834 https://doi.org/10.1007/s11626-997-0 021-6

[19] Bhat HK, Calaf G, Hei TK, et al. Critical role of oxidative stress in estrogen-induced carcinogenesis. Proc Natl Acad Sci USA. 2003; 100: 3913-3918.

[20] Available from: https://monographs.iarc.fr/ENG/Classif ication/ClassificationsAlphaOrder.pdf

[21] Available from: http://www.cancer.org/cancer/cancerca uses/othercarcinogens/medicaltreatments/menopausal -hormone-replacement-therapy-and-cancer-risk

[22] Brinton LA, Key TJ, Kolonel LN, et al. Prediagnostic Sex Steroid Hormones in Relation to Male Breast Cancer Risk. J Clin Oncol. 2015; 33: 2041-2050. PMid:25964249 https://doi .org/10.120 0/JC0.2014.59.1602 
[23] Nelles JL, Hu WY, Prins GS. Estrogen action and prostate cancer. Expert Rev Endocrinol Metab. 2011; 6: 437-451. PMid:21765856 https://doi.org/10.1586/eem.11.20

[24] Ho SM, Lee MT, Lam HM, et al. Estrogens and Prostate Cancer: Etiology, Mediators, Prevention, and Management. Endocrinol Metab Clin North Am. 2011; 40: 591-614. PMid:21889723 https: //doi.org/10.1016/j.ecl.2011.05.002

[25] Yeh CR, Da J, Song W, et al. Estrogen receptors in prostate development and cancer. Am J Clin Exp Urol. 2014; 2: 161-168.

[26] Conticello SG. The AID/APOBEC family of nucleic acid mutators. Genome Biol. 2008; 9: 229. Review.

[27] Roberts SA, Sterling J, Thompson C, et al. Clustered mutations in yeast and in human cancers can arise from damaged long singlestrand DNA regions. Mol Cell. 2012; 46: 424-35. PMid:22607975 https://doi.org/10.1016/j.molcel.2012.03.030

[28] Simonelli V, Narciso L, Dogliotti E, et al. Base excision repair intermediates are mutagenic in mammalian cells. Nucleic Acids Res. 2005; 33: 4404-4411. PMid:16077026 https ://doi .org/10.109 3/nar/gki749

[29] Alexandrov LB, Nik-Zainal S, Wedge DC, et al. Signatures of mutational processes in human cancer. Nature. 2013; 500: 415-421. PMid:23945592 https://doi.org/10.1038/nature12477

[30] Henderson S, Chakravarthy A, Su X, et al. APOBEC-mediated cytosine deamination links PIK3CA helical domain mutations to human papillomavirus-driven tumor development. Cell Rep. 2014; 7: 18331841. PMid:24910434 https://doi.org/10.1016/j.celrep. 2 014.05 .012

[31] Available from: http://www.cdc.gov/cancer/hpv/index.h tm

[32] Zhai K, Ding J, Shi HZ. HPV and lung cancer risk: a meta-analysis. J Clin Virol. 2015; 63: 84-90. https://doi.org/10.4178/epih /e2015052

[33] Bae JM, Kim EH. Human papillomavirus infection and risk of lung cancer in never-smokers and women: an 'adaptive' meta-analysis. Epidemiol Health. 2015; 37: e2015052.

[34] Bae JM. Human papillomavirus 16 infection as a potential risk factor for prostate cancer: an adaptive meta-analysis. Epidemiol Health. 2015; 37: e2015005.

[35] Yang L, Xie S, Feng X, et al. Worldwide Prevalence of Human Papillomavirus and Relative Risk of Prostate Cancer: A Meta-analysis Sci Rep. 2015; 5: 14667. PMid:26441160 https ://doi .org/10 $.1038 /$ srep 14667

[36] Li N, Bi X, Zhang Y, et al. Human papillomavirus infection and sporadic breast carcinoma risk: a meta-analysis. Breast Cancer Res Treat. 2011; 126: 515-520. PMid:20740311 https ://doi .org/10 $.1007 / \mathrm{s} 10549-010-1128-0$

[37] Damin DC, Ziegelmann PK, Damin AP. Human papillomavirus infection and colorectal cancer risk: a meta-analysis. Colorectal Dis. 2013; 15: e420-8.

[38] Svahn MF, Faber MT, Christensen J, et al. Prevalence of human papillomavirus in epithelial ovarian cancer tissue. A meta-analysis of observational studies. Acta Obstet Gynecol Scand. 2014; 93: 6-19.

[39] Jimenez-Pacheco A, Exposito-Ruiz M, Arrabal-Polo MA, et al. Metaanalysis of studies analyzing the role of human papillomavirus in the development of bladder carcinoma. Korean J Urol. 2012; 53: 240247. PMid:22536466 https://doi.org/10.4111/kju.2012.5 3.4 .240

[40] Chahoud J, Semaan A, Chen Y, et al. Association Between $\beta$-Genus Human Papillomavirus and Cutaneous Squamous Cell Carcinoma in Immunocompetent Individuals-A Meta-analysis. JAMA Dermatol. 2015 Dec 30.
[41] La Placa M, Ambretti S, Bonvicini F, et al. Presence of high-risk mucosal human papillomavirus genotypes in primary melanoma and in acquired dysplastic melanocytic naevi. Br J Dermatol. 2005; 152: 909-914. PMid:15888145 https://doi.org/10.1111/j.1365 $-2133.2005 .06344 . x$

[42] Ruer JB, Pépin L, Gheit T, et al. Detection of alpha- and beta-human papillomavirus (HPV) in cutaneous melanoma: a matched and controlled study using specific multiplex PCR combined with DNA microarray primer extension. Exp Dermatol. 2009; 18: 857-862. PMid:19469900 https://doi.org/10.1111/j.1600-0625.20 09.00866.x

[43] Ryoo NK, Kim JE, Choung HK, et al. Human papilloma virus in retinoblastoma tissues from Korean patients. Korean J Ophthalmol. 2013; 27: 368-371. PMid:24082775 https://doi .org/10.3341/ $\mathrm{kjo} .2013 .27 .5 .368$

[44] Rajendra S, Wang B, Merrett N, et al. Genomic analysis of HPVpositive versus HPV-negative oesophageal adenocarcinoma identifies a differential mutational landscape. J Med Genet. 2015 Oct 15.

[45] Xu WG, Zhang LJ, Lu ZM, et al. Detection of human papillomavirus type $16 \mathrm{E} 6 \mathrm{mRNA}$ in carcinomas of upper digestive tract. Zhonghua Yi Xue Za Zhi. 2003; 83: 1910-1914.

[46] Shukla S, Bharti AC, Mahata S, et al. Infection of human papillomaviruses in cancers of different human organ sites. Indian J Med Res. 2009; 130: 222-233.

[47] Simard EP, Ward EM, Siegel R, et al. Cancers with increasing incidence trends in the United States: 1999 through 2008. CA Cancer J Clin. 2012; 62: 118-128.

[48] Rombaldi RL, Serafini EP, Mandelli J, et al. Transplacental transmission of Human Papillomavirus. Virol J. 2008; 5: 106. PMid:18817577 https : //doi.org/10.1186/1743-422X-5-106

[49] Siegel RL, Miller KD, Jemal A. Cancer statistics, 2016. CA Cancer J Clin. 2016; 66: 7-30. PMid:26742998 https://doi .org/10. 332 2/caac. 21332

[50] Available from: http://www.cdc.gov/hpv/

[51] Merrill SJ, Subramanian M, Godar DE. Worldwide Cutaneous Malignant Melanoma Incidences Analyzed by Sex, Age, and Skin Type over Time (1955-2007): Is HPV infection of Androgenic Hair Follicular Melanocytes a Risk Factor for Developing Melanoma Exclusively in People of European-Ancestry? Dermato-Endocrinol. July 2016 https://doi.org/10.1080/19381980.2016.1215391

[52] Merrill SJ, Ashrafi S, Subramanian M, et al. Exponentially increasing incidences of cutaneous malignant melanoma in Europe correlate with low personal annual UV doses and suggests two major risk factors. Dermato-Endocrinol. 2015; 7(1): e1004018. https://doi.org/10.1080/19381980.2014.1004018

[53] Näsman A, Attner P, Hammarstedt L, et al. Incidence of human papillomavirus (HPV) positive tonsillar carcinoma in Stockholm, Sweden: an epidemic of viral-induced carcinoma? Int J Cancer. 2009; 125: 362-366.

[54] De Flora S, La Maestra S. Epidemiology of cancers of infectious origin and prevention strategies. J Prev Med Hyg. 2015; 56: E15-20.

[55] Griebeler ML, Kearns AE, Ryu E, et al. Secular trends in the incidence of primary hyperparathyroidism over five decades (1965-2010). Bone. 2015; 73: 1-7. https://doi.org/10.1016/j.bone. 201 4.12 .003

[56] Forrester JV, Xu H, Lambe T, et al. Immune privilege or privileged immunity? Mucosal Immunol. 2008; 1: 372-381.

[57] Cancer Incidence in Five Continents. Geneva: Union Internationale Contre le Cancer; 1966, 1970, 1976, 1982, 1987, 1992, 1997, 2002, 2007 and 2014. Available from: http://ci5.iarc.fr/CI5I-X/o ld/vol10/I_08.pdf 
[58] Fitzpatrick TB. The validity and practicality of Sun-reactive skin types I through VI. Arch Dermatol. 1988; 124: 869-871. https: //doi.org/10.1001/archderm.1988.01670060015008

[59] Available from: http://www.infoplease.com/ipa/A0855617. html

[60] Rohrmann S, Nelson WG, Rifai N, et al. Serum estrogen, but not testosterone, levels differ between black and white men in a nationally representative sample of Americans. J Clin Endocrinol Metab. 2007; 92: 2519-2525. PMid:17456570 https://doi.org/10.121 0/jc.2007-0028

[61] Ferrini RL, Barrett-Connor E. Sex hormones and age: a crosssectional study of testosterone and estradiol and their bioavailable fractions in community-dwelling men. Am J Epidemiol. 1998; 147: 750-754. https://doi.org/10.1093/oxfordjournals.aje.a 009519

[62] Chang ET, Blomqvist P, Lambe M. Seasonal variation in the diagnosis of Hodgkin lymphoma in Sweden. Int J Cancer. 2005; 115: 127-130. PMid:15660399 https://doi.org/10.1002/ijc. 20832

[63] Ho A, Gabriel A, Bhatnagar A, et al. Seasonality pattern of breast, colorectal, and prostate cancer is dependent on latitude. Med Sci Monit. 2014; 20: 818-824. PMid:24835144 https ://doi .org/10 .12659/MSM. 890062

[64] Hrushesky WJ, Sothern RB, Rietveld WJ, et al. Season, sun, sex, and cervical cancer. Cancer Epidemiol Biomarkers Prev. 2005; 14: 19401947. PMid:16103441 https ://doi .org/10.1158/1055-9965. EPI-04-0940

[65] Lambe M, Blomqvist P, Bellocco R. Seasonal variation in the diagnosis of cancer: a study based on national cancer registration in Sweden. Br J Cancer. 2003; 88: 1358-1360. PMid:12778061 https://doi.org/10.1038/sj.bjc.6600901

[66] Oh EY, Ansell C, Nawaz H, et al. Global breast cancer seasonality. Breast Cancer Res Treat. 2010; 123: 233-43. PMid:20130986 https://doi.org/10.1007/s10549-009-0676-7

[67] Ross JA, Severson RK, Swensen AR, et al. Seasonal variations in the diagnosis of childhood cancer in the United States. Br J Cancer. 1999; 81: 549-553. PMid:10507784 https://doi.org/10.1038/ sj.bjc.6690729

[68] Moskovic DJ, Eisenberg ML, Lipshultz LI. Seasonal fluctuations in testosterone-estrogen ratio in men from the Southwest United States. J Androl. 2012; 33: 1298-1304. PMid:22790643 https: //doi.org/10.2164/jandrol.112.016386

[69] El-Migdadi F, Nusier M, Bashir N. Seasonal pattern of leutinizing, follicle-stimulating hormone, testosterone and progesterone in adult population of both sexes in the Jordan Valley. Endocr Res. 2000; 26 : 41-48. https://doi.org/10.1080/07435800009040144

[70] Chen W, Clements M, Rahman B, et al. Relationship between cancer mortality/incidence and ambient ultraviolet B irradiance in China. Cancer Causes Control. 2010; 21: 1701-1709. PMid:20552265 https://doi.org/10.1007/s10552-010-9599-1

[71] Colli JL, Grant WB. Solar ultraviolet B radiation compared with prostate cancer incidence and mortality rates in United States. Urology. 2008; 71: 531-535. PMid:18342203 https://doi .org/10.1 016/j.urology.2007.10.050

[72] Cuomo RE, Mohr SB, Gorham ED, et al. What is the relationship between ultraviolet $\mathrm{B}$ and global incidence rates of colorectal cancer? Dermatoendocrinol. 2013; 5: 181-185. PMid:24494052 https://doi.org/10.4161/derm. 23773

[73] Fleischer AB Jr, Fleischer SE. Solar radiation and the incidence and mortality of leading invasive cancers in the United States. Dermatoendocrinol. 2016; 8: e1162366. https ://doi .org/10.1080/19 381980.2016 .1162366

Published by Sciedu Press
[74] Bilinski K, Boyages J. Association between 25-hydroxyvitamin D concentration and breast cancer risk in an Australian population: an observational case-control study. Breast Cancer Res Treat. 2013; 137: 599-607. PMid:23239153 https://doi.org/10.1007/s1 0549-012-2381-1

[75] Garland CF, Gorham ED, Mohr SB, et al. Vitamin D for cancer prevention: global perspective. Ann Epidemiol. 2009; 19: 468-483. PMid:19523595 https://doi.org/10.1016/j . annepidem. 20 09.03 .021

[76] Available from: https://www.google.com/webhp?sourceid= chrome-instant\&ion $=1 \&$ espv $=2 \&$ ie $=U T F-8 \# q=l$ if e + expect ancy+China

[77] FAO 2013, Current Worldwide Annual Meat Consumption per capita, Livestock and Fish Primary Equivalent, Food and Agriculture Organization of the United Nations, viewed 31st March, 2013.

[78] Hu FB. Globalization of diabetes: the role of diet, lifestyle, and genes. Diabetes Care. 2011; 34: 1249-1257. PMid:21617109 https : //doi.org/10.2337/dc11-0442

[79] Shim J, Pérez A, Symanski E, et al. Association Between Serum 25-Hydroxyvitamin D Level and Human Papillomavirus Cervicovaginal Infection in Women in the United States. J Infect Dis. 2016; 213: 1886-1892. PMid:26908722 https://doi.org/10.1093/ infdis/jiw065

[80] MacLaughlin J, Holick MF. Aging decreases the capacity of human skin to produce vitamin D3. J Clin Invest. 1985; 76: 1536-1538. PMid:2997282 https://doi .org/10.1172/JCI112134

[81] Tobin DJ. Aging of the hair follicle pigmentation system. Int J Trichology. 2007; 1: 83-93. PMid:20927229 https ://doi .org/10.4 103/0974-7753.58550

[82] Knight JA, Wong J, Blackmore KM, et al. Vitamin D association with estradiol and progesterone in young women. Cancer Causes Control. 2010; 21: 479-483. PMid:19916051 https://doi.org/10.1007/ s10552-009-9466-0

[83] Chung SH, Franceschi S, Lambert PF. Estrogen and ERalpha: culprits in cervical cancer? Trends Endocrinol Metab. 2010; 21: 504-511. PMid:20456973

[84] Brake T, Lambert PF. Estrogen contributes to the onset, persistence, and malignant progression of cervical cancer in a human papillomavirus-transgenic mouse model. Proc Natl Acad Sci USA. 2005; 102: 2490-2495. PMid:15699322 https://doi.org/10.1 073/pnas. 0409883102

[85] Foster JS, Henley DC, Bukovsky A, et al. Multifaceted regulation of cell cycle progression by estrogen: regulation of Cdk inhibitors and Cdc25A independent of cyclin D1-Cdk4 function. Mol Cell Biol. 2001; 21: 794-810. PMid:11154267 https://doi.org/10.1128/ MCB. $21 \cdot 3 \cdot 794-810.2001$

[86] Williams VM, Filippova M, Filippov V, et al. Human papillomavirus type 16 E6* induces oxidative stress and DNA damage. J Virol. 2014; 88: 6751-6761. PMid:24696478 https://doi .org/10.1128/JV I. 03355-13

[87] Lai D, Tan CL, Gunaratne J, et al. Localization of HPV-18 E2 at mitochondrial membranes induces ROS release and modulates host cell metabolism. PLoS One. 2013; 8: e75625. https://doi.org/ 10.1371/journal.pone. 0075625

[88] Karakas B, Bachman KE, Park BH. Mutation of the PIK3CA oncogene in human cancers. Br J Cancer. 2006; 94: 455-459. Review. PMid:16449998 https://doi.org/10.1038/sj.bjc.6602970

[89] Carestiato FN, Afonso LA, Moysés N, et al. An upward trend in DNA p16ink4a methylation pattern and high risk HPV infection according to the severity of the cervical lesion. Rev Inst Med Trop Sao Paulo. 2013; 55: 329-334. PMid:24037287 https ://doi.org/10.1590/ S0036-46652013000500006 
[90] Schlecht NF, Ben-Dayan M, Anayannis N, et al. Epigenetic changes in the CDKN2A locus are associated with differential expression of P16INK4A and P14ARF in HPV-positive oropharyngeal squamous cell carcinoma. Cancer Med. 2015; 4: 342-353. PMid:25619363 https://doi.org/10.1002/cam4.374

[91] Gallego MI, Lazo PA. Deletion in human chromosome region 12q13-15 by integration of human papillomavirus DNA in a cervical carcinoma cell line. JBC. 1995; 270: 24321-24326. https : //doi.org/10.1074/jbc.270.41.24321

[92] Nilbert M, Rydholm A, Mitelman F, et al. Characterization of the 12q13-15 amplicon in soft tissue tumors. Cancer Genet Cytogenet. 1995; 83: 32-36. https://doi.org/10.1016/S0165-4608(95 ) $00016-X$

[93] Dei Tos AP, Doglioni C, Piccinin S, et al. Coordinated expression and amplification of the MDM2, CDK4, and HMGI$\mathrm{C}$ genes in atypical lipomatous tumours. J Pathol. 2000; 190: 531-536. https://doi.org/10.1002/(SICI) 1096-989 6(200004) $190: 5<531:$ : AID-PATH579>3.0.CO;2-W

[94] Fetahu IS, Höbaus J, Kállay E. Vitamin D and the epigenome. Front Physiol. 2014; 5: 164. Review. PMid:24808866

[95] McDonnell SL, Baggerly C, French CB, et al. Serum 25Hydroxyvitamin D Concentrations $\geq 40 \mathrm{ng} / \mathrm{ml}$ Are Associated with $>65 \%$ Lower Cancer Risk: Pooled Analysis of Randomized Trial and Prospective Cohort Study. PLoS One. 2016; 11(4): e0152441. https://doi.org/10.1371/journal.pone.0152441
[96] Lappe JM, Travers-Gustafson D, Davies KM, et al. Vitamin D and calcium supplementation reduces cancer risk: results of a randomized trial. Am J Clin Nutr. 2007; 85: 1586-1591. PMid:17556697

[97] Giovannucci E, Liu Y, Rimm EB, et al. Prospective study of predictors of vitamin D status and cancer incidence and mortality in men. J Natl Cancer Inst. 2006; 98: 451-459. PMid:16595781 https://doi.org/10.1093/jnci/djj101

[98] Pimenoff VN, de Oliveira CM, Bravo IG. Transmission between archaic and modern human ancestors during the evolution of the oncogenic Human Papillomavirus 16 Mol. Biol. Evol. Advance Access published October 7, 2016. https : //doi.org/10.1093/mo lbev/msw214

[99] Adams JS, Hewison M. Unexpected actions of vitamin D: new perspectives on the regulation of innate and adaptive immunity. Nat Clin Pract Endocrinol Metab. 2008 Feb; 4(2): 80-90. https : //doi.org/10.1038/ncpendmet0716

[100] Sarkar S, Hewison M, Studzinski GP, et al. Role of vitamin D in cytotoxic T lymphocyte immunity to pathogens and cancer. Crit Rev Clin Lab Sci. 2016; 53: 132-145. PMid:26479950 https: //doi.org/10.3109/10408363.2015.1094443

[101] von Essen MR, Kongsbak M, Schjerling P, et al. Vitamin D controls $T$ cell antigen receptor signaling and activation of human T cells. Nat. Immunol. 2010; 11: 344-349. 